\title{
Ten Frequently Asked Questions for Small Business Start-Ups ${ }^{1}$
}

Henry M. Cothran, Allen Wysocki, and David Mulkey²

\section{Introduction}

"Take this job and shove it" is the title of a 1977 song written by Johnny Paycheck and David Alan Coe. The song expresses some of the frustration people experience when they lack control over their work life. If you have ever wondered what it would be like to be your own boss, this publication provides a series of questions to assist you in deciding whether owning your own business is right for you.

Every person starting a business will have questions along the way, and as soon as one question is answered another one arises. In fact, several questions may exist at the same time. This fact sheet presents ten questions that encapsulate the most important issues that must be addressed by those interested in starting a business:

1. Do I have what it takes to operate my own business?

2. What business should I start?
3. What do I do first?

4. How should I organize my business?

5. What permits or licenses do I need?

6 . How do I get people to buy my product/service?

7. Why do I need a business plan?

8. What are my alternatives for financing my business?

9. What kind of records do I need to keep?

10. Where can I go for help?

These ten questions address a central point in assessing your "readiness" to own and operate a business. Often each of the ten questions leads to more questions that must be answered. The following sections offer some guidance as you work through these questions toward the eventual goal of owning a business.

1. This is EDIS document FE571, a publication of the Department of Food and Resource Economics, Florida Cooperative Extension Service, Institute of Food and Agricultural Sciences, University of Florida, Gainesville, FL. Published September 2005. Please visit the EDIS website at http://edis.ifas.ufl.edu.

The information provided here is not intended as professional legal or accounting help. Contact an attorney and an accountant for advice specific to your business.

2. Henry M. Cothran, Associate-In; Allen Wysocki, Associate Professor; and David Mulkey, Professor and Associate Chair, Department of Food and Resource Economics, Florida Cooperative Extension Service, Institute of Food and Agricultural Sciences, University of Florida, Gainesville, FL. 


\section{Question 1: Do I have what it takes to operate a business?}

While you may have an idea for a business, the best place to start your planning process is to determine whether you "have what it takes" to start and operate a business. It is an important question and should be answered before starting a business. "Do I have what it takes?" requires an objective appraisal of your personal skills, abilities, and talents, as well as an assessment of your strengths, weaknesses, and personal situation, leading to the following questions:

- Am I a self-starter?

- Am I willing to take risks?

- Do I get along well with others?

- Can I make good decisions?

- Do I have the physical and emotional stamina to run a business?

- How well do I plan and organize?

- Can I maintain my motivation?

- Can I work alone?

- Can I blend the business with the family?

- Do I possess one or more of the following:

1. Money management skills

2. Industry experience and/or support

3. Technical experience and or support

4. Planning ability

While few people starting a new business possess all these qualities, all are important to business success, so you must do an honest assessment of your own talents, skills, and experience. To be successful, you must look for ways to compensate your weak areas, such as taking classes, reading, finding a mentor, hiring capable people, adding a partner with the necessary skills, or contracting for the needed help.

\section{Question 2: What business should I start?}

Once you have decided you have what it takes to operate your own business, your next task is to decide what kind of business you want to start. Again, you are the only person who can decide what business is best for you. As with Question 1, you begin by assessing your skills, abilities, and talents. Next you explore ways to use your skills and interests in a business and potential markets for your product/service.

In reviewing available options, you should consult with local experts and other business owners of the product/service you are proposing, and check with potential customers to see if they are willing to pay for that product/service. Your chance of success increases when you match a product/service with available or potential markets.

\section{Question 3: What do I do first?}

Once you have decided that starting a business is the right step for you and you have a doable business idea, there are several more steps to be completed before actually starting the business. These steps involve choosing a name and location for the business; registering the business with the proper authorities; obtaining the necessary licenses and permits; and developing production schedules and marketing and pricing plans. Take your time and plan carefully. Do not rush the process or skip any of the important steps/tasks.

\section{Question 4: How should I organize my business?}

Most small businesses are formed as sole proprietorships. The advantages of sole proprietorship are its simplicity and the fact that business income is treated the same as personal income for tax purposes. A significant disadvantage is that you, the owner, assume personal liability for the actions of the business.

Other types of business organization in Florida include general and limited partnerships, corporations and S corporations, and limited liability companies. Each type has its advantages and disadvantages. For 
information on ways to organize a business in Florida and the actions required for each organizational type, visit the Florida Department of State's website at http://www.dos.state.fl.us/startbus/index.html. In addition, you need to obtain expert legal and accounting help to determine the best legal structure for your business.

\section{Question 5: What permits or licenses do I need?}

Acquiring permits and licenses in Florida involve four issues:

1. Licensing and permitting regulations.

2. Zoning.

3. Sales and use taxes.

4. Employer identification numbers.

Licensing and permitting regulations vary with the type of business and the city, county, and state where the business is located. Some businesses face minimal licensing requirements while others are tightly controlled. Sources of information assistance include the local county Cooperative Extension Service, the local city or county clerks office, Small Business Development Centers, and the local Chamber of Commerce. Also, check with the Service Corps of Retired Executives and the Small Business Administration. Often information can be obtained from Enterprise Florida, local colleges/universities, or the Small Business Development Center in your community. Remember that in some cases both you as an individual and the business itself must have separate licenses.

Zoning is a concern for all businesses. The local planning and zoning office is an excellent place to start with questions about the physical location of your business. Governing bodies, typically the local city or county, are cautious in allowing a business to operate in residential areas. They want to avoid problems with traffic, noise, fumes, signs, or parking. Obtain the proper zoning permit before opening your business. If businesses are prohibited, learn if there is a waiver provision or if the ordinance can be changed. Do not just start the business. Without the necessary permit or waiver, local authorities can close the business immediately. As the owner, you can face civil and/or criminal penalties. Even with the proper permits, maintaining good relations with neighbors is good business.

Most Florida businesses need sales and use tax permits, which are available from the Florida Department of Revenue's website at http://www.myflorida.com/dor/taxes. Other important information is available at the main DOR website at http://www.myflorida.com/dor/businesses.

In addition to the sales and use tax permit, however, there is an Employer Identification Number (EIN) issued by the Internal Revenue Service. Sole proprietors who have no employees can use their personal social security number. All other businesses must obtain an EIN.

\section{Question 6: How do I get people to buy my product/service?}

Sales do not just happen. Sales happen because of marketing. Businesses use market research to identify their customers and what they want to buy. Marketing involves six issues, which are defined as:

1. Product: what are you producing and what benefits does it offer?

2. Production: how is it produced, at what rate, and what raw materials and time are used?

3. Price: at what price can the product or service be sold?

4. Promotion: how will potential customers know about the product or service?

5. Place: where is the business located and what distribution channels will be used?

6. Perception (or image): how should the customer see the business and the product or service provided? 


\section{Question 7: Why do I need a business plan?}

A business plan is the firm's résumé and lists its goals and objectives. Develop a business plan as much for yourself as for the partners, investors, and bankers involved with the business.

The business plan identifies the product/service, the market, the management team, where the business will operate, and your business experience. Parts of the plan include a market study, promotional strategies, current and projected balance sheets, income statements, and cash flow analyses. It outlines how, when, and where financial support will be obtained, and how to repay any loans made to the business. The plan provides general operating information, along with information about where the business is now, where it has been, and where it is going.

Business plans have three distinct uses: (1) feasibility and marketing plans; (2) operating (procedural) plans for financial needs, production schedules, and marketing goals; and (3) tools to secure loans or outside capital. Many resources are available to business owners for developing business plans, such as the Small Business Development Centers; the Service Corps of Retired Executives; computer software programs; and workshops offered by universities, community colleges, and vocational-technical schools.

\section{Question 8: What are the alternatives to help me finance my business?}

Your commitment of personal funds is often the first financing step. It is an indicator of how serious you are about the business. Risking personal money conveys your confidence to investors. Personal investment sources of capital include savings, current cash flow, second job income, home equity or equity from other property or assets, retirement accounts, personal lines of credit, and personal credit cards. All of these options include certain risks.

In addition to personal funds, family members and friends may be a source of financial help. Remember that successful loans from friends or relatives begin with a written document known as a contract. Contracts must clearly define the amount of the loan, interest rates, payment dates, amounts, etc. Signing a contract signifies agreement to the requirements of the contract. You may want to seek professional legal help in drawing up a contract.

Other, more complex financing options are also available, and again, should include professional legal and accounting assistance. Partnerships and incorporations must be in writing and filed with the clerk of the court. Business loans can be obtained from several sources, such as commercial banks and credit unions, commercial finance companies, local development companies, venture capital firms, and insurance companies. However, venture capital firms and insurance companies are typically not useful for owners of small businesses.

Excellent sources of financing information are your banker and the Small Business Administration. In Florida, your local Chamber of Commerce and Enterprise Florida can provide information on financing options. Another source of information is business incubators. Business incubators are facilities designed to assist businesses to become established and profitable during their startup phase. You can contact your local Chamber of Commerce about incubator locations.

\section{Question 9: What record do I need to keep?}

The records needed to manage the business and the records required by the IRS may differ. While the business owner is interested in where and how income is generated and where expenses are incurred, the IRS requires records that will allow for the preparation and documentation of a completed tax return. There are, however, basic financial records all businesses keep: journals and ledgers, such as a checkbook register, accounts receivable, accounts payable, records of sales, inventory, cash receipts, and cash disbursements. Records must also document mileage, meal expenses, and entertainment. If the business hires employees, additional records are required. Remember that all financial records are historical documents. This includes tax returns and the documentation for those returns. Business documents such as filing of the business name, 
incorporation/partnership papers, sales tax permit, federal employer identification number, and insurance records must be retained indefinitely.

Some of these records, such as incorporation papers and tax permits, must be kept for three or more years after the business closes. For yearly tax returns, the IRS says to keep the records for three years after the filing of that years taxes. Records involving property must be kept for the entire time the property is owned plus an additional three years minimum.

\section{Question 10: Where can I go for help?}

There are a wide variety of local, state, and national resources to help answer these and other questions. The local county Cooperative Extension Office is a good place to start. Ask if that office has a State or National Resource Directory for Small, Micro and Home-Based Businesses. Another good place to start is your local Florida Cooperative Extension Service (online at http://www.ifas.ufl.edu). Other resources and sources of information are listed in the Summary.

\section{Summary}

These ten questions only represent the beginning questions a potential business owner faces. Business owners may also need answers about insurance, intellectual property issues, employee issues, and independent contractors. The resources listed in this fact sheet are excellent places to get help for additional questions you may have. Take advantage of these available resources:

Florida Small Business Development Center Network http://www.floridasbdc.com/home.asp

Small Business Administration http://www.sba.gov/
North Florida District Office

7825 Baymeadows Way

Suite 100B

Jacksonville, FL 32256-7504

(904) 443-4900

http://www.sba.gov/fl/north/

South Florida District Office

100 South Biscayne Blvd, 7th Floor

Miami, FL 33131

(305) 536-5521

http://www.sba.gov/fl/south/

Womens Business Centers

http://www.sba.gov/wbc.html

Veterans Business Outreach Center

http://www.vboc.org/

SCORE On-line

http://www.score.org/

Small Business Training Network

http://www.sba.gov/training/

Disney/SBA National Entrepreneurial Center http://www.floridanec.org/ 
International Franchise Association

http://www.franchise.org/

The Franchise Opportunities Handbook

U.S. Government Printing Office

http://www.access.gpo.gov/

Thirty-one most asked questions about small business.

Small Business Administration

http://www.sba.gov/gopher/Menutext/busquest.txt 